慶應義塾大学学術情報リポジトリ

Keio Associated Repository of Academic resouces

\begin{tabular}{|c|c|}
\hline Title & $\begin{array}{l}\text { Acetylcholine synthesis is modulated by acetylcholine content of cytosolic fraction but not by that } \\
\text { of releasable fraction }\end{array}$ \\
\hline \multicolumn{2}{|l|}{ Sub Title } \\
\hline Author & $\begin{array}{l}\text { 鈴木, 岳之(Suzuki, Takeshi) } \\
\text { 鹿島, 裕子(Kashima, Yuko) } \\
\text { 藤本, 和子(Fujimoto, Kazuko) } \\
\text { 川島, 紘一郎(Kawashima, Koichiro) }\end{array}$ \\
\hline Publisher & 共立薬科大学 \\
\hline Publication year & 1992 \\
\hline Jtitle & $\begin{array}{l}\text { 共立薬科大学研究年報 (The annual report of the Kyoritsu College of } \\
\text { Pharmacy). No.37 (1992.) , p.86-86 }\end{array}$ \\
\hline \multicolumn{2}{|r|}{ (2, } \\
\hline \multicolumn{2}{|l|}{ Abstract } \\
\hline Notes & 抄録 \\
\hline Genre & Technical Report \\
\hline URL & $\begin{array}{l}\text { https://koara.lib.keio.ac.jp/xoonips/modules/xoonips/detail.php?koara_id=AN00062898-0000003 } \\
\text { 7-0086 }\end{array}$ \\
\hline
\end{tabular}

慶應義塾大学学術情報リポジトリ(KOARA)に掲載されているコンテンツの著作権は、それぞれの著作者、学会または出版社/発行者に帰属し、その権利は著作権法によって 保護されています。引用にあたっては、著作権法を遵守してご利用ください。

The copyrights of content available on the KeiO Associated Repository of Academic resources (KOARA) belong to the respective authors, academic societies, or publishers/issuers, and these rights are protected by the Japanese Copyright Act. When quoting the content, please follow the Japanese copyright act. 
No. 37 (1992)

\title{
Acetylcholine synthesis is modulated by acetylcholine content of cytosolic fraction but not by that of releasable fraction*
}

\author{
Takeshi Suzuki, Yuko Kashima, Kazuko Fujimoto
} and Koichiro KaWASHIMA

\section{鈴木岳之, 鹿島裕子, 藤本和子, 川島紘一郎}

Synthesis and release of acetylcltoline $(\mathrm{ACh})$ in the rat hippocampal slices were examined to clarify the mechanism of modulation of $\mathrm{ACh}$ synthesis. Treatment with 2- (4-phenylpiperidino) cyclohexanol (AH 5183, $50 \mu \mathrm{M}$ ), an inhibitor of ACh transport from cytosol to synaptic vesicles, inhibited the increase in ACh content of the membrane-bound fraction which is readily releasable, but did not affect the cytosolic ACh content. Under these conditions. The total $\mathrm{ACh}$ content reached a plateau value. These results indicate that ACh synthesis is modulated by cytosolic ACh content but not by the vesicular fraction.

* 本報告は Neuroscience Letters, 144（1992）127-129に発表. 